\title{
3
}

\section{MANAGING NIGERIA: REFLECTIONS AND PRESCRIPTIONS}

\section{R. A. Akindele}

A discussion and analysis of governance and democratic management of Nigeria's political order today ought to begin with two preposterous and fundamentally contentious claims being vigorously, but surreptitiously, smuggled by the Armed Forces leadership into political belief and practice in Nigeria. The first claim $u$ that the military, as an institution, has a divine right of governance and ruler ship through the barrel of the gun. In support of this proposition, attention is usually drawn to the fact that the military has been in power in Nigeria for approximately 24 of the 34 years of the country's postindependence history, While it is true that military rule has stopped being - mere aberration in Nigeria, the first claim certainly ignored both the politically unacceptable and imperial character of military rule and the historical fact that there have usually been loud and clear protests that the military has always been overstaying their welcome and vociferous demand for military disengagement from polities. The second claim which flows and is indeed linked up with the first is that Nigerians prefer a praetorian political order to democratic civil rule because, as alleged, the military offers better leadership and makes life more abundant for the Nigerian people than the elected political elites. Both claims are, to say the least, insulting, offensively provocative and spuriously fallacious.

While recognizing the provocative and fallacious character of both claims, analysis of the prescription for democratic governance and management of the political order in Nigeria should proceed from the transparent reality of an acute crisis of confidence in the nation's unity, corporate existence and stability. This crisis, created by the creeping and self-fulfilling military dictatorship which reached its pinnacle under General Babangida, was subsequently exacerbated by the peremptory annulment of the June 12 presidential election, generally believed to have been won by Bashorun M.K.O. Abiola of the now-defunct Social Democratic Party. The deepening crisis of confidence in Nigeria's collective identity provides a most welcome opportunity to begin to reexamine the nature and basis of Nigerian unity and, indeed, a signal for the need to be prepared to re-design, if need 
be, the political framework that is most suitable and appropriate for accommodating the territorially-structured diversities that exist prominently on Nigeria's social landscape.

Against the backdrop of the heated controversy and condemnation that greeted General Babangida's high-handed annulment of the June 12, 1993 presidential election, an election which, one might say, laid a solid and robust foundation for national unity hi a fundamental way that no other event has done in living memory, the first point that must be made and emphasized with all the strength at our command is that Nigerian unity cannot and should not, any more, be taken for granted. Therefore, the national question has to be discussed, but with realism and a sense of history; not with the prejudices of the present predicament and experience but with the long-term advantages of collective existence based upon justice, fairness and mutual respect. Indeed, the greatest challenge of political engineering in Nigeria today is how to design and construct a political structure for 'cohabitation' for the over 250 different ethnic groups in the society, bearing in mind the fact that any newly designed political structure must not only reflect but should indeed also be congruent with the preculiar character of the geographically-grouped principal diversities in the Nigerian society. As General Obasanjo recently put it, "after we have agreed to live together, we can settle the issue of how we will live together". There is much to be said for the view that the most appropriate choice for us in Nigeria today is neither between 'unitary" and 'federal' systems of government nor between 'confederal' and 'unitary* systems of government - not even between all of these on the one hand and balkanization/ethnic sovereignty on the other hand - but among the various types of federal system of government which exist. Those who, in their anger, now castigate federalism as an inappropriate political solution to our problem of finding 'unity hi diversities' unfortunately ignore the fact that there is no such tiling as the model of federalism. As a matter of fact, all federal systems can be placed on an analytical continuum ranging from the most peripheralized at the extreme left to the most centralized at the extreme right. The greatest challenge or task of constitutional engineering in a country such as Nigeria is the creative wisdom and political realism to search for and select the most appropriate type of federalism that congruently reflects the particular nature of the principal territorially-demarcated and structured diversities in Nigeria's federal society.

With the advantage of hindsight, it can be said confidently that the bane of federalism in Nigeria is that it has progressively become excessively centralized. This centralization has been accentuated and expedited more by 24 years of neo-imperial rule and governance by the Armed Forces than by other factors combined. Consensus now seems to be crystalizing behind the view that what we need today is a non-centralized federal system in which the state governments are politically virile, legislatively strong, financially resilient and, indeed, constitute self-confident and self-assertive centres of respect by, and political loyalty from, the citizens they serve and over whom they exercise authority. Many have argued that it is on the basis of these guidelines and credentials that we can conclude creatively the on-going fruitful debate and controversy on the constitutional structure for Nigeria, of course, bearing in 
mind and convinced that while the political efficiency profile of a 'true and balanced' federalism is unquestionably great and attractive, it cannot be realized and nurtured under a praetorian political order. Quite logically flowing from this observation is the proposition that needs to be advanced, namely that the greatest enemy of and impediment to Nigeria's federal unity, as earlier defined, is the military.

The federal solution to the constitutional problems of Nigerian unity is only one aspect, though a very important aspect, of the huge problem of how lo govern and manage Nigeria efficiently and effectively. Another aspect which requires identification and clarification is the particular form of government that permits the full realization of political and administrative efficiency from the complex machinery established for governance and for improving the productive capacity and welfare of the Nigerian people. Discussion on this issue usually focuses on the choice between the Westminster model of parliamentary government and the American model of executive presidentialism, both of which have been experimented with during Nigeria's short postindependence history. There is much to be said in favour of the marriage of federalism with executive presidential system of government. Perhaps the most persuasive defence of executive presidentlalism is that brilliantly articulated and succinctly summarized by General Obasanjo:

The greatest advantage of the presidential system is that the country is the constituency of the president. He is obliged to know the country and to seek support across the country. Even if he is a tribal baron, his horizon and outlook will be broadened by the end of a nationwide campaign. The system in which one person controls the executive and legislative bodies concentrates more power in that person than the one that separates the executive from the legislative.

The argument that the cost of running a presidential system of government is much higher than that of running the Westminster type of parliamentary democracy is largely hypothetical and requires unassailable empirical support to make it credible and respectable. In any case, the high political efficiency profile arising from coupling federalism with executive presidentialism is theoretically unquestionable, provided those who operate this particular federal machinery of government do not do so from the behavioural tradition and attitude flowing from and characteristic of the political culture of the Westminster model of parliamentary democracy, as was clearly the case during Nigeria's Second Republic.

\section{II}

As far as the task of managing Nigeria as a political order in this last decade of the 20th century and beyond is concerned, these aforementioned constitutional and institutional issues, important as they are, arc arguably 
secondary items on the agenda for any search for a politically effective structure and process for managing Nigeria's public affairs. On top of the agenda for action should be (i) the enthronement of the values and culture of participatory democracy, (ii) the expansion of the productive capacity of the national economy, (iii) the institutionalization of the principle of distributive justice in the sharing of the national wealth and (iv) the conception of the individual and his welfare as the centre of political life and action. Perhaps more importantly, as Nigeria prepares to evolve, hopefully, a permanent solution to its domestic crisis of national identity and development, there must also be a complementary adjustment and adaptation to the new demands and peculiarities of the New World Order if the country is to be congruently integrated into the political economy of this global village.

In the last decade, Nigerians have been going through two seemingly endless transitions. One is transition from military to civil rule. Under General Babangida, this transition had apparently been consciously made to follow a difficult political terrain with a 'hidden agenda' arguably because the doctrine of divine right of governance and rulership was still being religiously venerated by the military, notwithstanding its transparent anachronism. The other transition is from nee-imperial rule to democratic governance. Both transitions are interrelated. For quite obviously, a genuine and authentic democratic transformation cannot competently and dispassionately be initiated by the military who are part of, and indeed central to, the problem of dictatorship; nor can democratic process take off without structural hitches, let alone grow luxuriantly, in a political culture that has, for many years, been deeply polluted by the virus of military dictatorship.

Institutionalizing the democratic processes of periodically identifying those who govern us and authoritatively allocate values in our society, as well as deepening the democratic content of our thinking, is perhaps one of the most important conditions for effectively and harmoniously managing the political entity called Nigeria. Fortunately for us in this country, we can neither de-link nor distance ourselves from the contagious, bandwagon and demonstration effects of the whirlwind of democratization that has, more recently, engulfed the global community. This global democratic upsurge must strengthen our resolve to expedite the stalled transformation to democratic governance and make that transformation permanently irreversible in our country. As earlier pointed out, one formidable threat to democracy in Nigeria today is the military. Nigerian people must, therefore, consciously defend themselves by all means against the military's seemingly 'permanent aggression' against democratic forces, democratic tradition, democratic culture and democratic practices in this country. Any institution, including the military, that trivializes the genuine and profound preference of a people for democractic governance, particularly in this last decade of the century, wears the apparel of anachronism and will be unable to retain the deep loyalty of those people. The military, being the main cog in the wheel of democratization in most Third World countries and indeed central to the problem of anti-democratic governance in Nigeria, cannot and should not be a central participant in the search for solution to the problem of democratic governance in this country, that the military is in fact presiding over the 


\section{Annals of the Social Science Council of Nigeria, No.5, 1993}

processes of democratic transformation in Nigeria centrally raises a number of fundamental questions and, $a b$ initio, creates doubts about the strength of the democratic edifice merely being panel-beaten rather than completely reconstructed.

Democratizing the structure and processes of government including the authoritative allocation of values in Nigerian society, is one giant step in the movement towards a fundamental reform which an effective political management of Nigeria in this last decade of the 20th century requires.

The second step - or leg — in the analytic tripod of structural reforms - is the creative expansion of the productive capacity of the national economy and the institutionalization of the principle of distributive justice in the sharing of the national wealth. The deepening crisis in the national economy which surfaced dramatically in the early 1980s has its roots in (i) the monoculture, 'oil-command' character of the Nigerian economy; (ii) the gross mismanagement of the economy, and (iii) the virus of primitive accumulation and institutionalized corruption that corrosively weakened the fabric of the economy. Cumulatively, all of them considerably undermined and reduced the productive capacity of the economy, while at the same time fuelled the propensity for massive external borrowing which led to the extraordinarily embarrassing escalation of the debt burden from US $\$ 9$ billion in 1980 to US $\$ 35$ billion in 1989. This huge debt burden has definitely further strangulated the national economy and stunted development. Rebuilding the health and strength of the Nigerian economy must, in our view, begin with diversifying the sources of foreign exchange earnings through, for instance, paying greater attention to agricultural production, particularly for export purposes and end up with erecting and strengthening the ethics of honesty, frugality, integrity, transparency and accountability in the management of the country's economy and financial resources.

If production is one side of the economy-coin, the other side is distribution. Distributive justice in the sharing of the wealth and production of the economy among the competing territorially-organized groups in the federal society has, of necessity, become a critical factor which binds individual and group loyalty to the nation, strengthens the legitimacy character and taproot of the government of the day and consequently improves the stability profile of the political system. The concentration of federal expenditure for development in certain parts of the country, the insensitivity of the ruling class at the national level to the imperative of utilizing the equal opportunity principle in the distribution of national benefits, the marginalization of some sections of the Nigerian population, particularly the ethnic minorities, in the shaping of the structure of how values are authoritatively allocated in the society and the absence of equity and fairness in revenuesharing collectively constitute an impregnable assault on the important principle of distributive justice. All these now make more Nigerians to begin to ask the rhetorical but laoded question: Who is afraid of Nigeria's disintegration? The lesson of history and experience is that all Nigerians, including the Ogonis and Ijaws who produce a large percentage of the nation's wealth - crude oil - should be afraid of the disintegration of the country and should avoid putting the break-up of the country on the line. 

and fairness.

We should live together in one country but under renegotiated conditions of justice

Since the welfare of the individual is or should ultimately be the central concern and preoccupation of government in any democratic polity, the acid test of the efficacy of political management and public order-building in any country, including Nigeria, is the extent to which government in every country enables the individual to realize his potentialities. The issue of the welfare of the individual citizen in Nigeria is, of course, multifaceted. Two fronts call for brief comments. On the political front, the individual citizen has to be protected and insured against unjustifiable assault and indefensible en-chroachment by the government on his access to power, his human rights and fundamental freedoms, particularly the right of free expression of his views, the right of dissent against official views and the right of participation in the periodic processes of deciding who his rulers should be. A nation that trivializes the importance of and necessity for enchancing these rights of its people cannot count on the people's support and loyalty. In any case, such trivialization is bound to lead to a fundamental erosion of the legitimacy of the government and its political leadership and thus fuel a crisis of confidence among the generality of the people in the ability and willingness of the government to protect their interests.

The welfare of the Nigerian people also has to be addressed from the economic perspective; for, ultimately, as far as the common man is concerned, $\mathrm{k}$ is the "bread and butter' issue in politics that is central and more immediately critical to his existence. Thus, what is needed to satisfy his day-to-day needs is not just only a sound national economic policy that effectively mobilizes the energies and resources of the nation towards greater national productivity but also, and perhaps more importantly, a carefully mapped-out equitable redistributive policy that has an egalitarian and equalizing character. It is this that deepens his commitment to the nation and reassures him that it is indeed possible to establish a lasting framework for a more equitable and just society.

\section{Ill}

Finally, with the advantage of hindsight and comparative experience of other countries, a harmonious management of the Nigerian polity, preferably in a non-centralized federal form, requires, among other things (i) the clipping of the sharp edges of ethnicity which enables one, for instance, to narrow, if not close completely, the gap between 'citizenship' and 'indigeneship' rights, (ii) the building of the culture of secularity which dampens the potentially volatile role of religion, particularly the potency and pungency of the MuslimChristian divide, in national politics, (iii) a continuous attention to the study and monitoring of intergovernmental relations - vertically and horizontally, (iv) the establishment of a working tradition of diplomacy involving negotiation, bargaining and consensus-building in the management and resolution of conflict within the federation, and (v) the emergence of more purposeful, committed and astute leadership with good credentials, 
particularly honesty, integrity and humility. These issues require brief comments one by one. Ethnic nationalism which in Nigeria is territorially structured and geographically demarcated has very often been allowed, arguably unintentionally, to make one think that 'ethnic-state indigeneship' is more important and useful than 'Nigerian citizenship' in so far as it tends to make many Nigerian citizens technically 'aliens' in areas in Nigeria which are outside their ethnic roots of origin. But it needs to be emphasized that ideally no Nigerian citizen should be perceived as an 'alien', a 'local-foreigner' in any part of this country, even if by birth, over which he has no control, he is not considered to be an 'indigene' of a particular ethnic territory, notwithstanding the fact that he may have actually spent a considerable part of his life residing there. The cooling of the embers of ethnicity is certainly absolutely necessary to prevent the Hausa-Fulani from being 'aliens' in Sagamu or the Ibo from being treated as 'aliens' in Katsina. We have been reminded that "it is almost impossible to build an enduring nation-state in an arena where the government makes a fetish of local governments and states of origin". The 'indigene question', being part of the 'national question', requires to be fully addressed. The following suggestion by Jim Unah compels attention and careful consideration: "To obliterate the indigene question, let us simply decree, in a new Constitution, that any citizen of the Federal Republic of Nigeria who resides in a place other than his ethnic nationality area (ENA) is an indigene of that place with the right of access to all the opportunities offered therein". Perhaps we need to do much more than simply decreeing 'place of origin' out of our public documents; but we should begin somewhere now to find a lasting solution to the problem which the 'indigene question' poses for the 'national (citizenship) question'.

The acceptance or adoption of the principle of secularity is an important step forward in the battle against religious intolerance which has posed serious problems for many countries and shown signals that it could pose such problems for us in Nigeria. For peace, harmony and security in a religiously polycentric society like Nigeria, this battle has to be won. It is, however, not enough to merely have a constitutional prohibition against the adoption of a state religion on a constitutional declaration of the secularity of the State.

It is more important to go a step further to mobilize the general population and socialize them into the culture of religious tolerance which will make it possible for Nigerians in the Third Republic to insulate and isolate national politics from the debilitating influence of religious fanaticism and antagonism.

An important prescription for facilitating a harmonious management of Nigeria in the Third Republic and beyond is not only the continuous duty and monitoring of the problems of intergovernmental relations by academic and policy-oriented centres of excellence which possess respectable credentials and access to information on vertical and horizontal relations among the component units of the federation, but also the continuous interaction between such centres and the various governments in the country. Certainly toe most prestigeous of such institutional machinery for research and policy 
advice in Nigeria is the recently established National Council on Intergovernmental Relations. The NCIR, so far, has shown signs of being a positive influence as it identifies problem-areas in the management of the Nigerian federalism, prescribes solution to them, promotes co-operation among the tiers of government and, in its own ways, works towards a more harmonious Nigerian federation.

What is also critically required in ensuring the stability, unity and development of Nigeria in the years ahead are the diplomatic skills the various competing leaders at all levels of government bring to bear on the search for solution to their problems, particularly to the management and resolution of their conflicts. If the goal of diplomacy is consensus-building for a peaceful management of problems, its instrument and technique are negotiation and bargaining. The politics of intergovernmental relations in a federal polity like Nigeria certainly requires a great investment of resources on and attention to a peaceful resolution of issues by negotiation and bargaining; and by consensus, if possible.

In the final analysis, at the heart of Nigeria's problems and predicament it the failure of leadership. Recent history and experience in this country give one neither confidence nor hope on this issue. Leadership in the military has become progressively discredited. The best evidence of this is the fact that military leaders under General Babangida presided over what is unquestionably the most corrupt, dictatorial and oppressive regime in Nigeria's history. The resulting erosion of respectability and integrity weakened the fiber and fabric of the political system and created a serious credibility and acceptability problem for our leaders abroad. Much more despicable is the profile of opportunism and self-centredness which the political class in the Second Republic, particularly a large majority of the elected members of the last National Assembly, left behind. The hope for good governance and good leadership in the Third Republic has in fact become compromised and doubtful even before the on-going democratic transition process is completed tad actualized. The crisis, or more appropriately, the failure of leadership seeds to be frontally addressed. 